\title{
Pathological and Biochemical Characterization of Microcystin-Induced Hepatopancreas and Kidney Damage in Carp (Cyprinus carpio)
}

Pathological and Biochemical Characterization of MicrocystinInduced Hepatopancreas and Kidney Damage in Carp (Cyprinus carpio). Fischer, W. J., and Dietrich, D. R. (2000). Toxicol. Appl. Pharmacol. 164, 73- 81.

Mass occurrences of cyanobacteria, due to their inherent capacity for toxin production, specifically of microcystins (MC), have been associated with fish kills worldwide. The uptake of MC-LR and the sequence of pathological and associated biochemical changes was investigated in carp (Cyprinus carpio) in vivo over $72 \mathrm{~h}$. C arp were gavaged with a single sublethal bolus dose of toxic Microcystis aeruginosa (PCC 7806) amounting to an equivalent of $400 \mu \mathrm{g} \mathrm{MC}-\mathrm{LR} / \mathrm{kg}$ body wt. Damage of renal proximal tubular cells and hepatocytes was observed as early as $1 \mathrm{~h}$, followed by pathological changes in the intestinal mucosa at approximately $12 \mathrm{~h}$ postdosing. These alterations were characterized in hepatopancreas by a dissociation of hepatocytes, an early onset of apoptotic cell death, and delayed cell lysis. In the renal proximal tubules (P2) observations included increased vacuolation of individual tubular epithelial cells, apoptosis, cell shedding, and finally proteinaceous casts at the cortico-medullary junction. Concurrently with the pathological alterations, MC-immunopositive staining was observed in hepatocytes and the proximal tubular cells; the staining increasing in the hepatopancreas in intensity with increasing time postdosing. The presence of apoptotic cell death was determined using in situ fragment end labeling (ISE L) of the respective tissue sections and agarose gel electrophoresis for detection of DNA-laddering. The analysis of carp tissue extracts (hepatopancreas, kidney, GI tract, skeletal muscle, brain, heart, spleen, and gills) demonstrated MC-LR adducts having molecular weights of $38 \mathrm{kDa}$ (putatively catalytic subunit of protein phosphatases- 1 and $-2 A$ ) and 28 kDa, respectively. An additional band was found to be present at $23 \mathrm{kDa}$ in both hepatopancreas and kidney. The present data demonstrate that, in comparison to the pathological events in salmonids exposed to $M C$, where a slower development of pathology and primarily necrotic cell death prevails, the pathology in carp develops rapidly and at lower toxin concentrations. This is most likely due to a more efficient uptake of toxin, while the mechanism of cell death is primarily apoptosis. (c) 2000 Academic Press

${ }^{1}$ To whom correspondence should be addressed at Environmental Toxicology, University of Konstanz, Jacob-Burckhardtstr. 25, P.O. Box X-918, D-78457 Konstanz, Germany. Fax: 49-7531-883170; E-mail: Daniel. Dietrich@uni-konstanz.de.
Key Words: apoptosis; fish; histopathology; immunochemistry; liver; hepatopancreas; kidney; microcystin; protein phosphatase-1 and $-2 A$; toxin.

Toxic cyanobacterial (blue-green algal) blooms have been associated with the occurrence of fish kills primarily in freshwater but also in the marine environment (Schwimmer and Schwimmer, 1968; Peñaloza et al., 1990; Andersen et al., 1993; Rodger et al., 1994; Devidze, 1998). One of the major cyanobacterial toxin classes involved in these fish kills are the microcystins (MC), which are produced by several blue-green algal taxa (Watanabe et al., 1996; Carmichael, 1997). These monocyclic heptapeptide molecules contain both L- and Damino acids and an unusual hydrophobic $\beta$-amino acid commonly termed ADDA (3-amino-9-methoxy-2,6,8-trimethyl10-phenyldeca-4,6-dienoic acid). In many of the 50 known MC congeners, the five D-amino acid moieties are maintained while the two L-amino acids are variable (Botes et al., 1985; Rinehart et al., 1994). MC-LR, containing L-Leu and L-Arg is one of the most commonly occurring (Watanabe et al., 1996) and, at the same time, among the most toxic congeners (Rinehart et al., 1994).

Analysis of feral fish kills suggested that mostly cyprinid species and to a lesser extent percids, esocids, and salmonids are affected by toxic cyanobacterial blooms (Table 1). The question therefore was raised, why cyprinids appear more susceptible for cyanobacterial intoxications than other classes of fish. One important aspect may be that toxic cyanobacteria need to be ingested in order to induce damage (Tencalla and Dietrich, 1997; Fischer et al., 2000). Cyprinids are generally speaking omnivorous, but obligate herbivorous and cyanobacterivorous members are also known (Winfield and Nelson, 1991). In contrast, salmonids take up cyanobacteria involuntarily. Therefore, the observation that primarily cyprinid species are affected by toxic cyanobacterial blooms may be just a question of the amount of toxin that is ingested, rather than a species-specific effect.

A comparison of rainbow trout and carp gavaged with MC-LR containing lyophilized cyanobacteria (Tencalla, 1995) indicated that carp were more susceptible to the toxin(s) than 
TABLE 1

Some Species Reported Involved in Fish K ills Occurring during E pisodes of Massive Cyanobacterial Blooms

\begin{tabular}{|c|c|c|c|c|}
\hline Family & Species & Habitat & Diet & Reference \\
\hline \multirow[t]{4}{*}{ Cyprinidae } & Tench (Tinca tinca) & & $\begin{array}{l}\text { Larvae, worms, molluscs } \\
\text { (bottom-feeders) }\end{array}$ & Stadelmann (1984) \\
\hline & Bream (Abramis brama) & $\begin{array}{l}\text { Slow-flowing or } \\
\text { stagnant waters }\end{array}$ & $\begin{array}{l}\text { Zooplankton, insects, larvae, } \\
\text { molluscs, plant material }\end{array}$ & $\begin{array}{l}\text { Stadelmann (1984), Lindholm } \\
\text { (personal communication) }\end{array}$ \\
\hline & Roach (Rutilus rutilus) & & $\begin{array}{l}\text { Zooplankton, insects, larvae, shrimp, } \\
\text { molluscs }\end{array}$ & $\begin{array}{l}\text { Stadelmann (1984), Lindholm } \\
\text { (personal communication) }\end{array}$ \\
\hline & Carp (Cyprinus carpio) & & $\begin{array}{l}\text { Zooplankton, insects, larvae, } \\
\text { molluscs, plant material }\end{array}$ & Peñaloza et al. (1990) \\
\hline Percidae & Perch (Perca fluviatilis) & Slow-flowing waters & Larvae, worms, molluscs, fish & $\begin{array}{l}\text { Stadelmann (1984), Lindholm } \\
\text { (personal communication) }\end{array}$ \\
\hline Esocidae & Pike (Exox lucius) & Lakes & $\begin{array}{l}\text { Voracious carnivore: frogs, birds, fish, } \\
\text { aquatic animals }\end{array}$ & $\begin{array}{l}\text { Stadelmann (1984), Lindholm } \\
\text { (personal communication) }\end{array}$ \\
\hline \multirow[t]{4}{*}{ Salmonidae } & Stint (Osmerus eperlanus) & $\begin{array}{l}\text { Coastal waters, } \\
\text { breed in freshwater }\end{array}$ & $\begin{array}{l}\text { Insects, worms, small fish, drifting } \\
\text { animals }\end{array}$ & Stadelmann (1984) \\
\hline & Coregonid (Coregonus albula) & Lakes & $\begin{array}{l}\text { Mainly plankton (14\% can be } \\
\text { molluscs and insects) }\end{array}$ & Lindholm (personal communication) \\
\hline & Brown trout (Salmo trutta) & Lakes & $\begin{array}{l}\text { Insects, worms, small fish, drifting } \\
\text { animals }\end{array}$ & \\
\hline & Atlantic salmon (Salmo salar) & $\begin{array}{l}\text { Coastal waters, } \\
\text { breed in freshwater }\end{array}$ & $\begin{array}{l}\text { Zooplankton, worms, molluscs, insect } \\
\text { larvae, algae when young }\end{array}$ & Tencalla $(1995)^{a}$ \\
\hline
\end{tabular}

\footnotetext{
${ }^{a}$ With permission.
}

trout (Table 2). Again, the question may be raised whether this susceptibility is a mere dose effect, i.e., the amount of toxin taken up from the gastrointestinal tract (GI) during GI passage of the bolus dose. Indeed, the latter is strongly suggested by the fact that identical intraperitoneal bolus doses of MC $(550 \mu \mathrm{g}$ $\mathrm{MC}$ per $\mathrm{kg}$ ) lead to mortality in carp and rainbow trout within a comparable time frame, i.e., within $24 \mathrm{~h}$ (Råbergh et al., 1991; Tencalla et al., 1994), while an oral dose of $550 \mu \mathrm{g} \mathrm{MC}$ per $\mathrm{kg}$ in rainbow trout resulted in no mortality at all (Tencalla et al., 1994). If, therefore, the species difference in susceptibility of rainbow trout and carp were due to differing uptake capacities of MC in the gastrointestinal tract, one would have to expect the same type of pathology in carp and in rainbow trout when given an identical dose of toxin or cyanobacterial lyophilisate. However, the pathological changes, appearing primarily in the liver and only secondarily in the kidney of exposed animals, would be expected to occur much earlier in carp than in rainbow trout. Death of the fish is assumed to result from the extensive liver damage (see below) rather than from an hypovolemic shock as indicated in mammals (Råbergh et al., 1991; Tencalla et al., 1994).

Rainbow trout gavaged with lyophilized cyanobacteria ( $\mathrm{Mi}$ crocystis aeruginosa, strain PCC 7806) at acutely toxic doses of $5700 \mu \mathrm{g}$ MC per kg body wt, revealed a time-dependent discernible inhibition of hepatic protein phosphatases- 1 and $-2 \mathrm{~A}$ and the concurrent induction of hepatocyte necrosis, also expressed as increased plasma LDH, GOT, and GTP levels (Tencalla and Dietrich, 1997), MC-immunopositivity in the cytoplasm as well as the nuclei of hepatocytes, apoptotic cell death as of $48 \mathrm{~h}$ following gavage, and death evolving within $96 \mathrm{~h}$ (Fischer et al., 2000). If indeed the higher susceptibility of carp to MCs is a question of toxicokinetics and not of toxico-

TABLE 2

Toxicity of Microcystin-LR to Carp and Trout

\begin{tabular}{|c|c|c|c|c|c|c|c|c|}
\hline \multirow[b]{2}{*}{ Toxin } & \multirow[b]{2}{*}{$\begin{array}{c}\text { Algae } \\
(\mathrm{mg} / \mathrm{kg} \mathrm{bw})\end{array}$} & \multirow[b]{2}{*}{$\begin{array}{c}\text { Toxin } \\
(\mu \mathrm{g} / \mathrm{kg} \text { bw) }\end{array}$} & \multicolumn{3}{|c|}{ Trout } & \multicolumn{3}{|c|}{ Carp } \\
\hline & & & $\begin{array}{c}\text { Liver } \\
\text { damage }\end{array}$ & $\begin{array}{l}\text { Lethality to } \\
\text { treated fish }\end{array}$ & $n$ & $\begin{array}{c}\text { Liver } \\
\text { damage }\end{array}$ & $\begin{array}{l}\text { Lethality to } \\
\text { treated fish }\end{array}$ & $n$ \\
\hline \multirow[t]{2}{*}{ MC-LR } & 1440 & 6600 & Severe & Within 72-96 h & 18 & Severe & Within $10 \mathrm{~h}$ & 6 \\
\hline & 370 & 1700 & None & None & 18 & Severe & Within $24-48 \mathrm{~h}$ & 18 \\
\hline
\end{tabular}

Note. Toxicity to carp (Cyprinus carpio) and trout (Oncorhynchus mykiss) of microcystin-LR (MC-LR) contained in the cyanobacteria Microcystis aeruginosa PCC 7806. Testing was carried out with freeze-dried material suspended in dechlorinated water via oral gavage. $n$, number of fish per treatment group; bw, body weight. From Tencalla (1995) with permission. 
dynamics, then the same pathological changes as described in the rainbow trout should be observed, albeit at an earlier time point. If, however, the pathological changes in rainbow trout and carp are dissimilar, then the difference in susceptibility may be related to cellular toxicodynamics.

In order to better understand the effects of MCs in carp, yearling carp were administered acutely toxic doses of the MC-producing cyanobacteria Microcystis aeruginosa PCC 7806 via gavage. The presence of MC was monitored immunohistochemically with anti-MC antibodies in the hepatopancreas and kidney and in tissue homogenates of various other organs using Western blotting. The levels of MC present in the kidney and hepatopancreas was compared to the degree of pathological changes observed in a time-dependent manner. In addition, the form of cell death (necrosis vs. apoptosis) was characterized using pathomorphological assessment, histochemistry via in situ-end-labeling (ISEL), and DNA agarose gel electrophoresis (DNA-laddering).

\section{MATERIALS AND METHODS}

Fish. Yearling carp (Cyprinus carpio, $n=30$ ) with a mean weight of $21 \pm 6 \mathrm{~g}$, were purchased from a local fish hatchery. The carp were kept at a water temperature of $15 \mathrm{C}$ in dechlorinated tap water under continuous aeration. Feeding of pellet food at a rate of $1 \%$ of the body weight per day was terminated 2 days before initiation of the experiment.

Prior to bolus application, fish were anesthetized with tricaine $(200 \mathrm{mg} / \mathrm{liter}$ ethyl 3-aminobenzoate methanesulfonate, Fluka, Switzerland). The bolus dose of approximately $0.5 \mathrm{ml}$ suspension of freeze-dried $M$. aeruginosa in dechlorinated tap water, amounting to an equivalent of $400 \mu \mathrm{g}$ MC-LR per $\mathrm{kg}$ body wt, was directly applied into the fish stomachs using blunt-tip gavage syringes (Asic, Denmark). Three test and two control fish were killed at 1, 3, 12, 24, 48, and $72 \mathrm{~h}$ after bolus dosing and tissue samples (hepatopancreas, kidney, muscle, GI tract, brain, heart, spleen, and gills) were collected for subsequent histopathological, immunohistochemical, and/or Western blot analysis as well as for DNA extraction (DNA-laddering).

Histopathology. Tissue samples were routinely fixed in $4 \%$ neutral buffered formalin for several hours, dehydrated, paraffin-embedded, and archived. Sections of 3-5 $\mu \mathrm{m}$ were mounted on aminopropyltriethoxysilane-coated slides (APTS, A-3648, Sigma). Following deparaffinization in xylene, sections were rehydrated, stained with hematoxylin and eosin (H \& E), and mounted with Crystal/Mount (Biømeda) for later pathological assessment.

Immunohistochemistry. Sections of paraffin-embedded tissues were deparaffinized as described above, rehydrated, and incubated with type XIV bacterial protease (P-5147, Sigma) in PBS for antigen retrieval at $37 \mathrm{C}$ for 15 min. Endogenous peroxidase was blocked with $3 \% \mathrm{H}_{2} \mathrm{O}_{2}$ for 15 min. Endogenous biotin was blocked with a specific avidin/biotin blocking kit (Vector). Rabbit anti-MC-LR antibodies (Mikhailov et al., submitted for publication) were applied in a humidified atmosphere for $16-20 \mathrm{~h}$ at $4 \mathrm{C}$. Antigen-primary antibody complex visualization was achieved using biotin-conjugated secondary antibodies (multi link, BioGenex), horseradish peroxidase-labeled streptavidin, and DAB-chromogen (Super Sensitive, BioGenex). Sections were counterstained for $15 \mathrm{~s}$ with hematoxylin, rinsed in tap water, and mounted with Crystal/Mount (Biømeda).

Detection of apoptotic/necrotic cell death. Detection of apoptotic nuclei/ bodies in paraffin-embedded tissue sections was achieved by evaluation of nuclear morphology in $\mathrm{H} \& \mathrm{E}$ stained tissue sections and by histochemical ISEL of DNA. The latter was performed using an in situ DNA-fragment end labeling kit (FragEL, Oncogene) according to the manufacturer's instructions.

Apoptotic cell death and necrosis were distinguished in hepatopancreas samples using agarose gel electrophoresis, where the presence of DNAladders, i.e., high-molecular-weight DNA fragments, and DNA-smears were considered indicative of apoptosis and necrosis, respectively. Small pieces $(\sim 0.3 \mathrm{~g})$ of hepatopancreas were homogenized 1:5 in ice-cold TBE-buffer ( 89 $\mathrm{mM}$ Tris-base, $89 \mathrm{mM}$ boric acid, $10 \mathrm{mM}$ EDTA) using six strokes at full speed of a Potter-Elvehjem homogenizer. Cellular debris was centrifuged for $15 \mathrm{~min}$ at $20,000 \mathrm{~g}$ and $4 \mathrm{C}$. After homogenization and centrifugation of hepatopancreas tissue, the DNA was precipitated from $450 \mu$ l supernatant by addition of $1 \mathrm{ml}$ cold ethanol $(-20 \mathrm{C})$ and $50 \mu \mathrm{l}$ sodium acetate $(3 \mathrm{M})$ and stored at $-20 \mathrm{C}$ until further extraction for analysis on agarose gels. Briefly, the sample was digested repetitively with proteinase-K and RNAse, and DNA was extracted with the phenol/chloroform method and separated on $1.5 \%$ agarose gels. After staining with ethidium bromide, DNA bands in the gel were visualized by UV illumination $(312 \mathrm{~nm})$ and photographed.

Western blot analysis. The presence of MC-LR in carp tissues was analyzed using Western blot analysis. Carp tissue samples (hepatopancreas, kidney, GI tract, muscle, brain, heart, spleen, and gills) were homogenized in 20 $\mathrm{ml}$ ice-cold extraction buffer (10 mM Tris, $\mathrm{pH} 7.5 ; 140 \mathrm{mM} \mathrm{NaCl} ; 5 \mathrm{mM}$ EDTA; 1 mM PMSF; 1 mM DTT; $1 \%$ Triton X-100) per gram tissue using a Potter-Elvehjem homogenizer and six strokes at full speed. Coarse debris was pelleted by centrifugation for $10 \mathrm{~min}$ at $5000 \mathrm{~g}$ and $4 \mathrm{C}$. The protein contents of the resulting supernatant were determined and the supernatant was subsequently frozen at $-80 \mathrm{C}$ until further analysis. Proteins $(60 \mu \mathrm{g} / \mathrm{lane})$ of the various carp tissues were separated using $12 \%$ SDS-PAGE in a standard fashion. Following electrophoresis, proteins were blotted onto nitrocellulose membranes and probed with a rabbit anti-MC affinity purified polyclonal antibody (Mikhailov et al., submitted for publication). The secondary antibody was an alkaline phosphatase-conjugated sheep anti-rabbit antibody (Roche Biochemicals, Germany) while FastRed (F-4648, Sigma) was used as chromogen.

\section{RESULTS}

\section{Mortality and Gross Morphology}

No fish died during the initial gavaging with MC-containing cyanobacterial suspension or throughout the subsequent $72-\mathrm{h}$ test period. Visual inspection of the gastrointestinal tract at the intermittent sampling time points $(1,3,12,24$, and $48 \mathrm{~h})$ and at termination of the experiment at $72 \mathrm{~h}$ demonstrated a progradient yellowish discoloration in hepatopancreas of treated fish with increasing time postdosing. No overt gross pathological changes could be observed in any of the other organs.

\section{Histopathology}

Control carp presented with normal histology (Figs. 1A, 1D, $2 \mathrm{~A}$, and 2D). In contrast, carp gavaged with toxic cyanobacteria, presented with pathological changes in hepatopancreas, kidney, and gastrointestinal tract, which increased in severity with increasing time postdosing (Table 3 ), as presented in detail below. All other tissues examined (muscle, brain, heart, spleen, and gills) did not present with any pathological changes.

\section{Hepatopancreas}

Alterations in the structural organization of hepatocytes were observed $1 \mathrm{~h}$ after gavage. These alterations appeared to be initially restricted to the pericentral region of the hepato- 

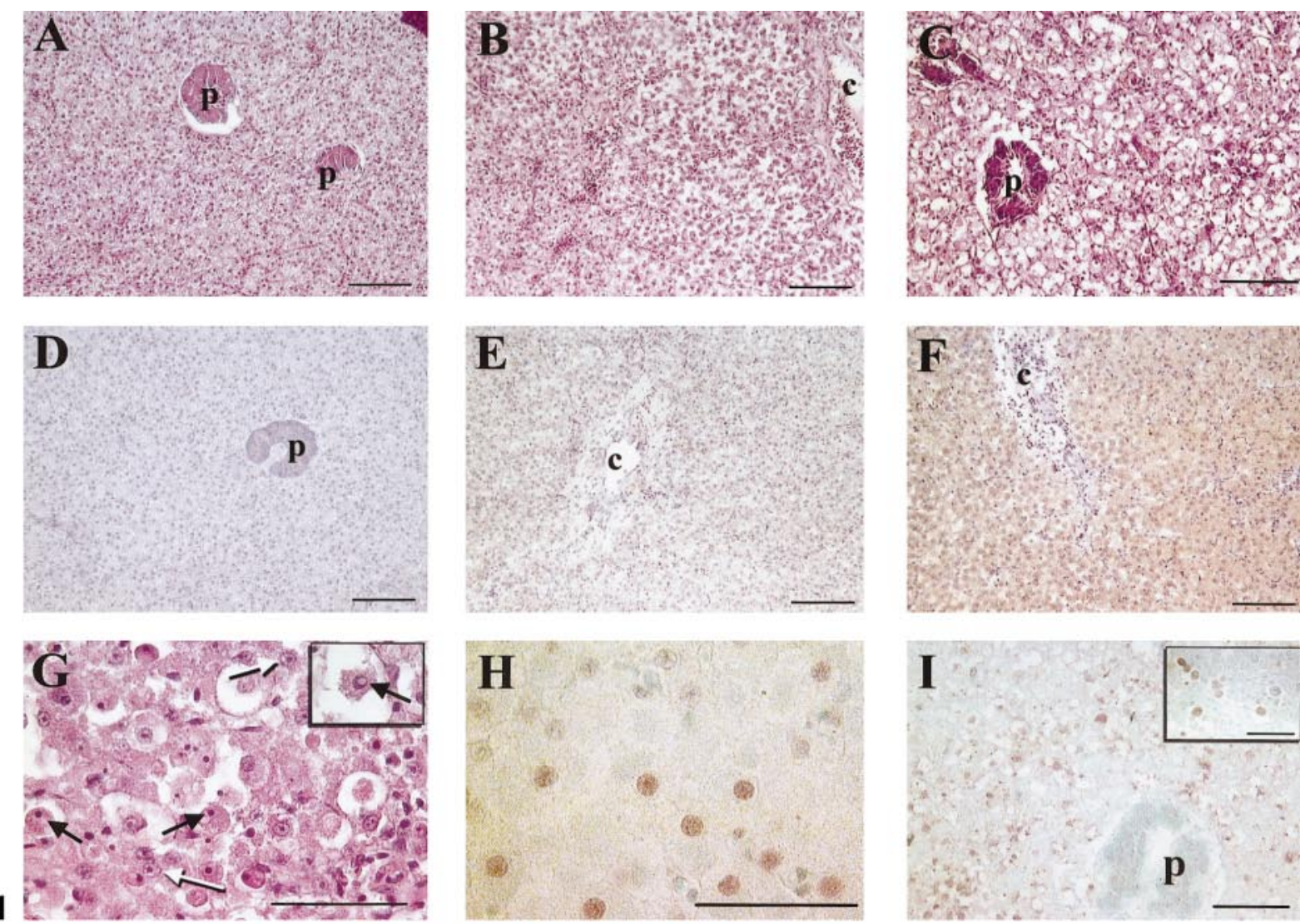

$A$
20
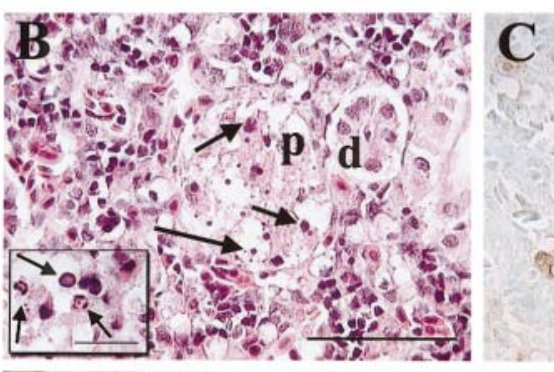

W

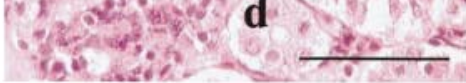
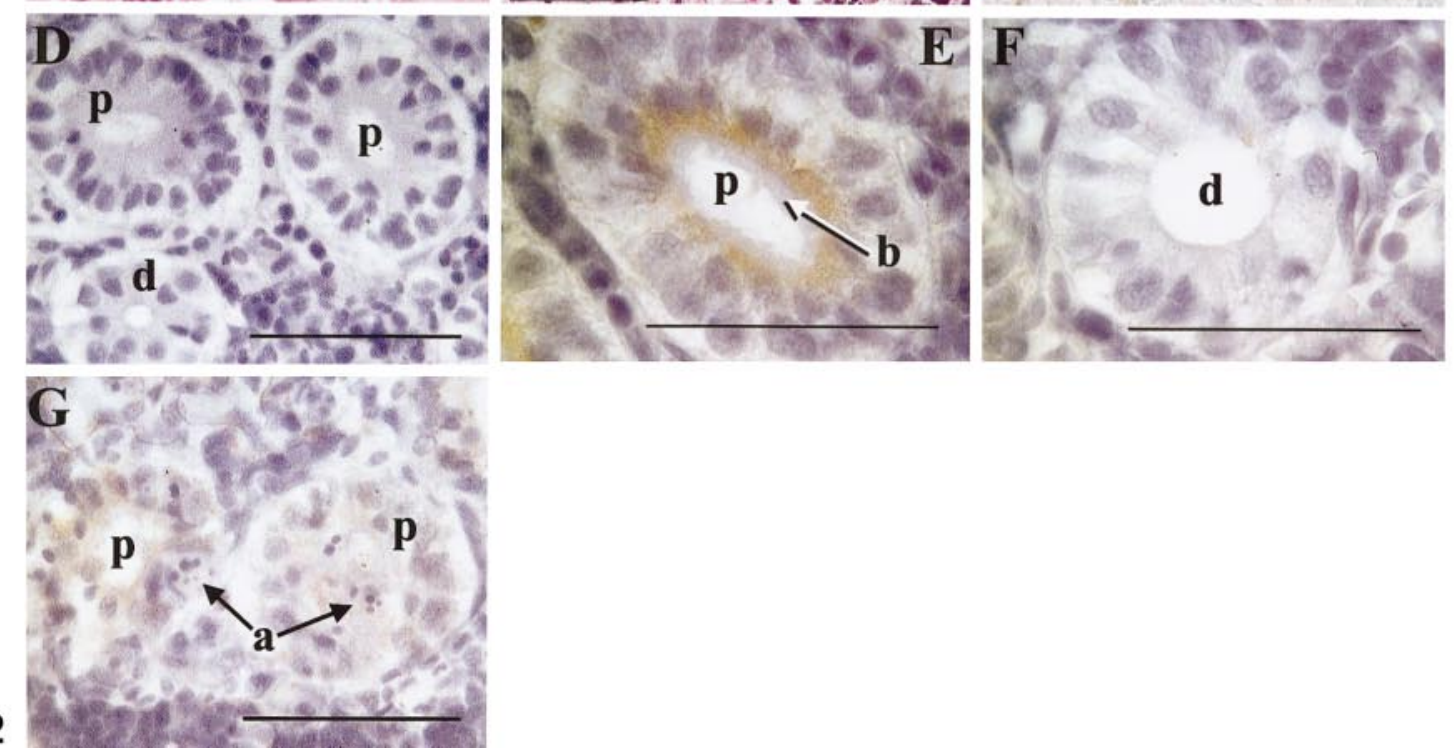
pancreas (Fig. 1B). With increasing time, hepatopancreas damage became more conspicuous and involved larger areas of the hepatopancreas. Pathology was characterized by a time-dependent rounding of hepatocytes, including condensed cytoplasms and contact loss between hepatocytes (Figs. 1B and 1C). Between 1 and $24 \mathrm{~h}$ after gavage, the latter changes became progressively more conspicuous and dispersed throughout the hepatopancreas (Table 3). An apparent lysis of hepatocyte membranes (necrotic cells) was observed to begin as of $48 \mathrm{~h}$ postdosing. In many cases this was associated with the appearance of pyknotic/apoptotic nuclei (Fig. 1G) and apoptotic figures (Fig. 1G and inset).

\section{Kidney}

Degenerative changes were observed 1 to $3 \mathrm{~h}$ postgavage involving primarily proximal tubular cells (P1 and P2). These changes were characterized by increased vacuolation of individual tubular epithelial cells, pyknosis, apoptosis (Fig. 2B and inset), cell lysis, and exfoliation of epithelial cells into the tubular lumen. As of $12 \mathrm{~h}$ these changes involved whole tubules (Fig. 2B and 2G), leading to the formation of proteinaceous casts at the cortico-medullary junction (figure not shown). As of $24 \mathrm{~h}$, pathological changes in the tubules increased to the point where only remnants of the tubules remained, i.e., the tubular structure had disintegrated (figures not shown). Although pathological changes were observed in the glomeruli, especially in the mesangia, these appeared secondary to the pathological changes in the proxima.

\section{GI Tract}

Pathological changes in the GI tract were observed after $12 \mathrm{~h}$ postdosing. These changes were characterized by pyknotic nuclei and apoptotic cells lining the intestinal mucosa. The latter alterations increased in severity, also involving cell shedding and in some cases localized hemorrhage, culminating at $24 \mathrm{~h}$ postdosing and then receding in severity (data not shown).

\section{Apoptosis}

Morphological alterations of nuclei consistent with those characteristic for apoptosis (Wyllie et al., 1980) were observed in $\mathrm{H} \&$ E-stained hepatopancreas (Fig. $1 \mathrm{G}$ and inset) and kidney sections (Fig. 2B and inset) as of $12 \mathrm{~h}$ and $1 \mathrm{~h}$ postdosing, respectively. Histochemical ISEL corroborated the observations made in the $\mathrm{H} \& \mathrm{E}$ sections in that ISEL-positive staining was found in the nuclei of hepatocytes as of $12 \mathrm{~h}$ postdosing (Fig. 1H). ISEL-positive staining increased in intensity, reaching the highest levels at $72 \mathrm{~h}$ postdosing (Table 3, Fig. 1I, and inset). In carp kidneys, histochemical ISEL was positive as of $3 \mathrm{~h}$ on. The highest intensity of ISEL-positive staining was reached at $12 \mathrm{~h}$ (Fig. 2C) after which staining intensity decreased (Table 3) concurrently with the increased appearance of proteinaceous casts at the corticomedullary junction, figure not shown). Apoptosis as observed in the $\mathrm{H} \&$ E-stained sections of the GI tract was also demonstrable with ISEL; ISEL-positive staining reaching the maximum at $24 \mathrm{~h}$ postdosing and then fading over the continued time course (data not shown).

The time pattern of occurrence of apoptosis in the hepatopancreas of treated carp was also corroborated by the analysis of nuclear DNA high-molecular-weight-fragmentation (DNAladdering) using agarose gel electrophoresis. Indeed, the earliest evidence of DNA-laddering became visible at $12 \mathrm{~h}$ postgavage, increasing in prominence with time (Fig. 3; Table 3). At $72 \mathrm{~h}$ a slight reduction in laddering intensity was observed, possibly commensurate with the increased liquefaction of the hepatopancreas tissue also observed at this time point (vide supra).

\section{Immunohistochemistry}

MC immunopositive staining was observed $1 \mathrm{~h}$ postdosing, in the hepatopancreas (Figs. 1E and 1F; Table 3) as well as in the tubular epithelial cells of the kidney (Figs. 2E and 2G; Table 3). In hepatopancreas, positive staining intensity increased progressively with increasing time postdosing (Figs. $1 \mathrm{E}$ and $1 \mathrm{~F}$; Table 3). In the kidney MC-immunopositivity was restricted to the proximal tubular cells, primarily the $\mathrm{P} 2$ and to a lesser extent the P1 section. The P3 section did not appear to be involved (figure not shown) nor was any immunopositivity observed in the distal cells (Fig. 2F). Staining was specifically localized in the apical part of the epithelial cells (Fig. 2E),

FIG. 1. Pathological changes, microcystin immunopositive staining, and ISEL of nuclear DNA, taken as representative for apoptosis, in hepatopancreas of carp (Cyprinus carpio) gavaged with Microcystis aeruginosa (PCC 7806) equivalent to $400 \mu \mathrm{g}$ microcystin-LR/kg body wt. (A-C) H \& E-stained hepatopancreas sections of (A) control carp; (B) $1 \mathrm{~h}$ postdosing: pericentral rounding and dissociation of hepatocytes; (C) $48 \mathrm{~h}$ postdosing: extensive damage spread throughout the section with highly condensed nuclei and cytolysis. (D-F) Immunohistochemical staining for MC-LR (D) control section; (E) $1 \mathrm{~h}$ postdosing: immunopositivity above control; (F) $12 \mathrm{~h}$ postdosing: maximal immunopositivity. (G-I) Characterization of apoptotic nuclei (G and inset) 48 h postdosing (H \& E): highly condensed chromatin (black arrows) and normal appearing nuclei (white arrows); (H and I) ISEL-stained sections depicting apoptotic nuclei at 12 and $72 \mathrm{~h}$ postdosing, respectively. p, pancreas; c, central vein. Bars in A-F, $100 \mu \mathrm{m}$, bars in G-I, $50 \mu \mathrm{m}$.

FIG. 2. Pathological changes, microcystin immunopositive staining and ISEL of nuclear DNA, taken as representative for apoptosis, in kidney of carp (Cyprinus carpio) gavaged with Microcystis aeruginosa (PCC 7806) equivalent to $400 \mu \mathrm{g}$ microcystin-LR/kg body wt. (A-C) H \& E-stained kidney sections of (A) control carp; (B) $12 \mathrm{~h}$ postdosing: P2 proximal tubule (p), vacuolated cells with highly condensed apoptotic nuclei (black arrows); (C) ISEL-stained serial section of B depicting apoptotic nuclei at $12 \mathrm{~h}$ postdosing. (D-G) Immunohistochemical staining for MC-LR (D) control section; (E) $1 \mathrm{~h}$ postdosing: immunopositive staining in the apical region of $\mathrm{P} 2$ proximal epithelial cells; (F) $3 \mathrm{~h}$ postdosing: MC-LR immunonegativity in distal tubules; (G) $12 \mathrm{~h}$ postdosing: immunopositive staining and apoptotic bodies (black arrows) in proximal tubular cells. a, apoptotic nuclei; b, brush-border; d, distal tubule; p, proximal tubule. Bars, $50 \mu \mathrm{m}$. 


\begin{tabular}{|c|c|c|c|c|c|c|}
\hline \multirow[b]{2}{*}{ Time (h) } & \multirow[b]{2}{*}{ Organ } & \multirow[b]{2}{*}{ Pathology } & \multirow[b]{2}{*}{ Western blot } & \multirow[b]{2}{*}{ Immunohistochemistry* } & \multicolumn{2}{|c|}{ Apoptosis } \\
\hline & & & & & ISEL & DNA-laddering \\
\hline \multirow[t]{6}{*}{1} & Kidney & 1 & nd & 1 & 0 & nd \\
\hline & Hepatopancreas & 1 & nd & 1 & 0 & 0 \\
\hline & Muscle & 0 & nd & 0 & 0 & nd \\
\hline & GI tract & 0 & nd & 0 & 0 & nd \\
\hline & Brain & nd & nd & nd & nd & nd \\
\hline & Heart, spleen, gills & 0 & nd & 0 & 0 & nd \\
\hline \multirow[t]{6}{*}{3} & Kidney & 2 & nd & 2 & 1 & nd \\
\hline & Hepatopancreas & 2 & nd & 2 & 0 & 0 \\
\hline & Muscle & 0 & nd & 0 & 0 & nd \\
\hline & GI tract & 0 & nd & 0 & 0 & nd \\
\hline & Brain & nd & nd & nd & nd & nd \\
\hline & Heart, spleen, gills & 0 & nd & 0 & 0 & nd \\
\hline \multirow[t]{6}{*}{12} & Kidney & 3 & nd & 2 & 3 & nd \\
\hline & Hepatopancreas & 3 & nd & 3 & 1 & 1 \\
\hline & Muscle & 0 & nd & 0 & 0 & nd \\
\hline & GI tract & 1 & nd & 0 & 0 & nd \\
\hline & Brain & nd & nd & nd & nd & nd \\
\hline & Heart, spleen, gills & 0 & nd & 0 & 0 & nd \\
\hline \multirow{6}{*}{24} & Kidney & 3 & nd & 1 & 2 & nd \\
\hline & Hepatopancreas & 3 & nd & 3 & 2 & 2 \\
\hline & Muscle & 0 & nd & 0 & 0 & nd \\
\hline & GI tract & 2 & nd & 0 & 0 & nd \\
\hline & Brain & nd & nd & nd & nd & nd \\
\hline & Heart, spleen, gills & 0 & nd & 0 & 0 & nd \\
\hline \multirow[t]{6}{*}{48} & Kidney & 4 & 3 & 1 & 2 & nd \\
\hline & Hepatopancreas & 4 & 4 & 3 & 3 & 3 \\
\hline & Muscle & 0 & 2 & 0 & 0 & nd \\
\hline & GI tract & 1 & 1 & 0 & 0 & nd \\
\hline & Brain & nd & 1 & nd & nd & nd \\
\hline & Heart, spleen, gills & 0 & 0 & 0 & 0 & nd \\
\hline \multirow[t]{6}{*}{72} & Kidney & 4 & nd & 1 & 1 & nd \\
\hline & Hepatopancreas & 5 & nd & 3 & 3 & 2 \\
\hline & Muscle & 0 & nd & 0 & 0 & nd \\
\hline & GI tract & 0 & nd & 0 & 0 & nd \\
\hline & Brain & nd & nd & nd & nd & nd \\
\hline & Heart, spleen, gills & 0 & nd & 0 & 0 & nd \\
\hline
\end{tabular}

Note. Pathology, MC-Western blots, MC-immunohistochemistry, and apoptosis were scored: 0, no effect (pathology/staining/laddering) present; 1 , effect (pathology/staining/laddering) present; 2, moderate effect (pathology/staining/laddering); 3, medium effect (pathology/staining/laddering); 4, strong effect (pathology/staining/laddering); 5, very strong effect (pathology/staining/laddering); nd, not determined.

* Immunohistochemistry with antimicrocystin antibodies.

however not involving the brush-border (Figs. 2E and 2G). MC-immunopositive staining was generally localized to the proxima, but involved only approximately $30 \%$ of the tubules at a given time point.

\section{Western Blot Analysis}

Immunoblotting of tissue homogenates with anti-MC-LR antibody revealed three protein bands $(38,28$, and $23 \mathrm{kDa})$ in the kidney and hepatopancreas of treated carp not observed in the respective controls (Fig. 4). Common to all of the tissues investigated (hepatopancreas, kidney, GI tract, muscle, and brain) was a conspicuous protein band and a minor band with approximately molecular weights of 38 and $28 \mathrm{kDa}$, respectively (Fig. 4). The kidney and hepatopancreas homogenates demonstrated the highest signal intensity compared to the other tissues, although this observation is not adequately represented with the contrast-adjusted Fig. 4. 


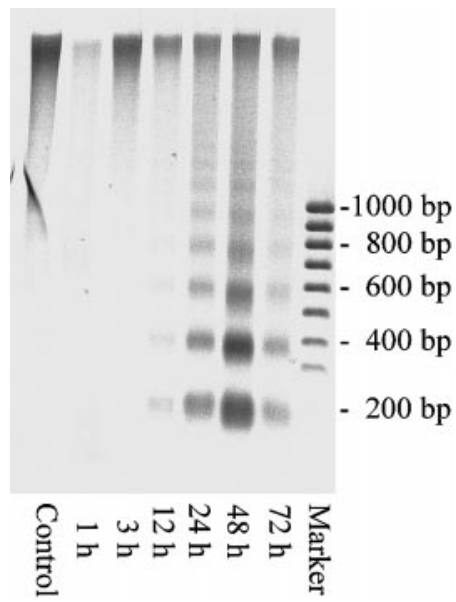

FIG. 3. Nuclear DNA fragmentation in hepatopancreas of carp (Cyprinus carpio) gavaged with Microcystis aeruginosa (PCC 7806) equivalent to 400 $\mu \mathrm{g}$ microcystin-LR/kg body wt. First signs of DNA-laddering, indicative of apoptotic cell death, are visible at $12 \mathrm{~h}$ postdosing. (black and white inverted for better contrast).

\section{DISCUSSION}

A $400 \mu \mathrm{g} / \mathrm{kg}$ MC-LR equivalent bolus oral dose led to severe pathological changes in the hepatopancreas and kidney of exposed carp; however, no mortality was observed. An earlier experiment with $800 \mu \mathrm{g} / \mathrm{kg}$ MC-LR equivalent bolus oral dose led to $100 \%$ mortality within $72 \mathrm{~h}$ postdosing (W. Fischer, unpublished data). Similarly, higher oral doses, i.e., 6600 and $1700 \mu \mathrm{g} / \mathrm{kg}$ MC-LR equivalent bolus oral dose, led to mortality within 10 and 24-48 h (Table 2), respectively (Tencalla et al., 1994), while $250 \mu \mathrm{g} / \mathrm{kg}$ MC-LR resulted in pathological changes of the hepatopancreas and gills of the carp, although without mortality within the 7-day experimentation period (Carbis et al., 1996). The central question of how much of the orally applied dose is taken up by carp from the gastrointestinal tract and thus can act systemically may be answered indirectly via the comparison of the oral and ip doses that lead to mortality and tissue damage. Indeed, identical intraperitoneal doses of MC (550 $\mu \mathrm{g}$ MC per $\mathrm{kg}$ ) lead to mortality in carp and rainbow trout within a comparable time frame, i.e., within 24 h (Råbergh et al., 1991; Tencalla et al., 1994), while an oral dose of $550 \mu \mathrm{g}$ MC per $\mathrm{kg}$ in rainbow trout resulted in no mortality and only minor pathological changes in the livers (Tencalla et al., 1994). Råbergh et al. (1991) also injected carp with 100-300 $\mu \mathrm{g} / \mathrm{kg}$ MC-LR ip and reported that this single application led to pathological changes in the liver and kidney only. The pathological changes observed following application of 300 and $550 \mu \mathrm{g} / \mathrm{kg}$ ip MC-LR were of a lower and higher severity, respectively, than those observed in the study presented here with $400 \mu \mathrm{g} / \mathrm{kg}$ MC-LR equivalent bolus oral dose. Based on the assumption that $100 \%$ of the ip dose reach the hepatopancreas of the carp, the data presented here therefore suggest that nearly $100 \%$ of the oral
MC dose applied is resorbed from the gastrointestinal tract in carp.

The latter suggestion is supported by two additional observations: $\mathrm{MC}$ was demonstrated to be predominantly taken up via the ileum, although this observation was made in rats (Dahlem et al., 1989). Bile acids were shown to enter the blood stream primarily via passive diffusion from the ileum in fish (Honkanen and Patton, 1987) as well as in rabbits (Aldini et al., 1995), but also via organic-anion carriers (Frimmer and Ziegler, 1988). Therefore, the greater the surface and length of the ileum, the greater the amount of bile acids that can enter the blood stream per unit time.

Although MCs are not analogous to bile acids, MCs were demonstrated to possess a high affinity for organic-anion carriers in competition with bile acids (Eriksson et al., 1990; Runnegar et al., 1995). Concerning ileal uptake of MCs, it is therefore highly likely that MC will behave similar to bile acids and therefore will be taken up rapidly and efficiently, but also in direct dependency to the length and surface area of the ileum. This notion is also supported by the observations of Bury et al. (1998) who also reported passive diffusion as well as inhibited active transport of $\mathrm{MC}$ from the rainbow trout GI tract to the bloodstream. However, only approximately $0.3 \%$ of the dose orally applied into the GI tract was detectable in the tissues.

There are several differences in the GI tract anatomy between carp and trout. Rainbow trout, as carnivorous fish, have a stomach with pyloric caeca and a very short ileum, whereas planktivorous and herbivorous cyprinids as well as cichlids possess a long ileum with a large surface area and high resorptive capacities (Kapoor et al., 1975). It is likely that a larger amount of orally applied MC enters the blood stream per unit

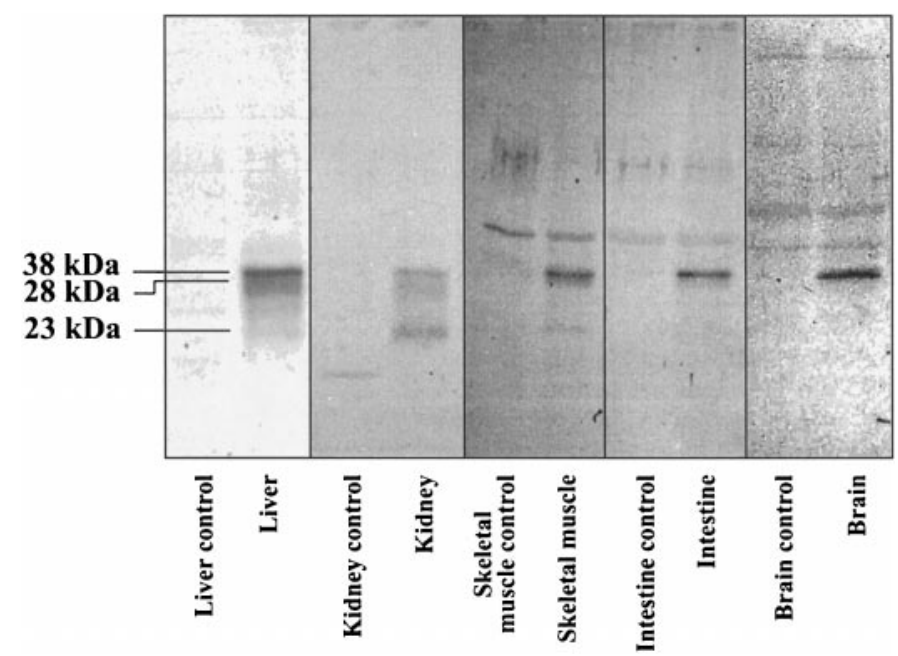

FIG. 4. Western blot of tissue extracts from control and microcystin (MC)-treated carp (Cyprinus carpio). Anti-MC antibody was used for detection of proteins adducted with MC. Sixty micrograms of protein was applied to each lane. For better visualization, the contrast of muscle-, GI tract-, and brain blots was enhanced by approximately $35 \%$. 
time in the carp. Assuming equivalent cardiac output in carp and trout, pathological changes would be expected to appear much earlier in carp than in trout. Indeed pathological changes were observed as early as $1 \mathrm{~h}$ postadministration in the kidney and hepatopancreas of MC-treated carp (Table 3, Figs. 1 and 2).

Although protein phosphatase inhibition in the liver of MC treated rainbow trout was also observed already starting at $1 \mathrm{~h}$ postdosing, these changes resulted from an oral dose of 5700 $\mu \mathrm{g} / \mathrm{kg}$ body wt, i.e., a 14 -fold higher dose than that applied in the carp (Tencalla and Dietrich, 1997). In addition, MC was detected in the hepatopancreas and kidney of treated carp at $1 \mathrm{~h}$ after gavage, while MC-immunopositive staining in rainbow trout livers was not detected until $12 \mathrm{~h}$ after treatment (Fischer et al., 2000). Furthermore, while the pathological changes observed in the livers of rainbow trout and carp appeared similar at first sight, detailed analysis demonstrated that indeed the genesis of the alterations was different in the two species.

In rainbow trout the primary mechanism of pathological damage appeared to involve the inhibition of protein phosphatases- 1 and $-2 \mathrm{~A}$ and the concurrent induction of hepatocyte necrosis (Tencalla and Dietrich, 1997). Apoptosis was detectable only very late in the sequence of pathological changes of the liver (48 $\mathrm{h}$ after treatment) and was interpreted as only of secondary nature (Fischer et al., 2000). In contrast, apoptosis was apparent as early as $1 \mathrm{~h}$ and $12 \mathrm{~h}$ postdosing in the kidney and hepatopancreas of treated carp, respectively, while the number of necrotic cells appeared to be negligible. Indeed, apoptosis progressively increased to such an extent that, as of $12 \mathrm{~h}$, DNA-laddering was detectable in DNA extracted from the hepatopancreas of treated carp (Fig. 3). The latter pathological changes thus suggest that, in carp, the kidney is affected first, while pathological changes in the hepatopancreas appear slightly later, and that the primary mechanism of cell death in carp is apoptosis rather than necrosis as observed in the rainbow trout.

The pathological changes in the kidney of carp were specifically located to the P2 section of the proxima, a segment known for its high capacity of active protein and peptide reabsorption. Indeed, the MC immunohistochemistry also demonstrated MC to be present in the apical side of the proximal epithelial cells. In view of the observation that MCs are predominantly absorbed via the ileum and transported via the iliac vein and the hepatopancreatic portal vein to the hepatopancreas and the heart (Yasutake and Wales, 1983), thus partially by-passing the hepatopancreas, it is not surprising to find pathological changes in the kidney. Furthermore, as soon as most of the MC is reabsorbed from the GI tract, little additional MC would reach the kidney, especially as the MC that reaches the hepatopancreas will either be irreversibly bound or excreted as conjugates via the bile (Sahin et al., 1995, 1996; Pflugmacher et al., 1998). It is thus not surprising to observe highest MC immunopositivity between 3 and 12 hours postdosing (Fig. 2E; Table 3).
Although the activity of protein phosphatases-1 and -2A was not determined in the carp hepatopancreas and kidney samples, the Western blots of the various carp tissues, demonstrated the presence of a protein-adduct with $\mathrm{MC}(\sim 1 \mathrm{kDa})$ having a molecular weight of $38 \mathrm{kDa}$ (Fig. 4), i.e., corresponding to the catalytic subunit of protein phosphatases 1 and $2 \mathrm{~A}(37 \mathrm{kDa})$, which is generally believed to be a target molecule for covalent binding with MC (MacKintosh, 1993). A similar protein band was observed in rainbow trout hepatocytes treated with MC in vitro (Hitzfeld et al., 1999) and was tentatively identified via Western blot as being protein phosphatase-2A. In addition to this $38-\mathrm{kDa}$ protein band, two other protein bands ( 28 and 23 $\mathrm{kDa}$ ) were observed in hepatopancreas and kidney. While the $28 \mathrm{kDa}$ was also found in muscle, GI tract, and brain, the $23-\mathrm{kDa}$ protein band was detectable only in hepatopancreas and kidney. The detection of MC protein-adducts in skeletal brain and muscle tissue of fish is a novelty, especially as similar experiments using radiolabeled MC failed to demonstrate the presence of MC in these tissues in salmon (Salmo salar) (Williams et al., 1995) and only minute levels were reported in carp (Bury et al., 1998).

The comparison of MC uptake and induced pathology as well as presence of MC protein adducts in salmonids and carp as discussed above suggest that decisive differences exist between the two species to microcystin intoxications. Furthermore, in view of the fact that carp are being reared in hypereutrophied ponds, prone to infestations with cyanobacterial blooms and the fact that microcystin can be demonstrated in the muscle tissue of carp exposed to moderate but not lethal concentrations of microcystin indicate that the human risk assessment process should differentiate risk emanating from muscle tissue from rainbow trout and carp contaminate with microcystin, respectively.

\section{ACKNOWLEDGMENTS}

The authors thank Dr. John Eriksson and Dr. Andrey Mikhailov for providing the anti-MC antibody, Dr. Ya-Juin Chou for help with the Western blot analyses, Dr. Gerald Künstle and Hannes Hentze for help with the DNA analysis, Dr. Francesca Tencalla for permission to use Tables 1 and 2, and Dr. Bettina Hitzfeld for discussing the manuscript. This project was funded in part by the European Commission DG XII, INCO-Copernicus Project ERBIC15CT961010.

\section{REFERENCES}

Aldini, R., Roda, A., Montagnani, M , and Roda, E. (1995). Bile acid structure and intestinal absorption in the animal model. Ital. J. Gastroenterol. 27, 141-144.

Andersen, R. J., Luu, H. A., Chen, D. Z. X., Holmes, C. F. B., Kent, M. L., Le Blanc, M., Taylor, F. J. R., and Williams, D. E. (1993). Chemical and biological evidence links microcystins to salmon "netpen liver disease." Toxicon 31, 1315-1323.

Botes, D. P., Wessels, P. L., Kruger, H., Runnegar, M. T. C., Santikarn, S., Smith, R. J., Barna, J. C. J., and Williams, D. H. (1985). Structural studies on cyanoginosins-LR, -YR, -YA, and -YM, peptide toxins from Microcystis aeruginosa. J. Chem. Soc. Perkin Trans. 1, 2747-2748.

Bury, N., Newlands, A., Eddy, F., and Codd, G. (1998). In vivo and in vitro 
intestinal transport of ${ }^{3} \mathrm{H}$-microcystin-LR, a cyanobacterial toxins, in rainbow trout (Oncorhynchus mykiss). Aquat. Toxicol. 42, 139-148.

Carbis, C., Rawlin, G., Mitchell, G., Anderson, J., and McCauley, I. (1996). The histopathology of carp, Cyprinus carpio L., exposed to microcystin by gavage, immersion and intraperitoneal administration. J. Fish Dis. 19, 199-207.

Carmichael, W. W. (1997). The cyanotoxins. In Advances in Botanical Research, pp. 211-256. Academic Press, New York.

Dahlem, A. M., Hassan, A. S., Swanson, S. P., Carmichael, W. W., and Beasley, V. R. (1989). A model system for studying the bioavailability of intestinally administered microcystin-LR, a hepatotoxic peptide from the cyanobacterium Microcystis aeruginosa. Pharmacol. Toxicol. 64, 177-181.

Devidze, M. (1998). Harmful algal events in Georgian waters. In Harmful Algae (B. Reguera, J. Blanco, L. Fernández, and T. Wyatt, Eds.), p. 91. Xunta de Galicia and Intergovernmental Oceanographic Commission of UNESCO.

Eriksson, J. E., Grönberg, L., Nygård, S., Slotte, J. P., and Meriluoto, J. A. O. (1990). Hepatocellular uptake of ${ }^{3} \mathrm{H}$-dihydromicrocystin-LR, a cyclic peptide toxin. Biochim. Biophys. Acta 1025, 60-66.

Fischer, W. F., Hitzfeld, B. C., Eriksson, J. E., Mikhailov, A., and Dietrich, D. R. (2000). Microcystin-LR toxicodynamics, induced pathology and immunohistochemical detection in livers of rainbow trout. Toxicol. Sci. (in press).

Frimmer, M., and Ziegler, K. (1988). The transport of bile acids in liver cells. Biochim. Biophys. Acta 947, 75-99.

Hitzfeld, B. C., Fischer, W. F., Eriksson, J. E., Mikhailov, A., and Dietrich, D. R. (1999). Immunochemical detection of microcystin-LR in tissues and cells of rainbow trout. Toxicol. Sci. 48(Suppl.) 33.

Honkanen, R. E., and Patton, J. S. (1987). Bile salt absorption in killifish intestine. Am. J. Physiol. 253, G730-G736.

Kapoor, B. G., Smith, H., and Verighina, L. A. (1975). The alimentary canal and digestion in teleosts. Adv. Mar. Biol. 13, 109-239.

MacKintosh, C. (1993). Assay and purification of protein (serine/threonine) phosphatases. In Protein Phosphorylation A Practical Approach (D. G. Hardie, Ed.), pp. 197-229. Oxford University Press, Oxford.

Mikhailov, A., Härmälä-Brasken, A.-S., Meriluoto, J., Sorokina, Y., Dietrich, D. R., and Eriksson, J. E. Production and specificity of mono- and polyclonal antibodies against microcystins conjugated through $\mathrm{N}$-methyldehydroalanine. Submitted for publication.

Peñaloza, R., Rojas, M., Vila, I., and Zambrano, F. (1990). Toxicity of a soluble peptide from Microcystis sp. to zooplankton and fish. Freshwater Biol. 24, 233-240.

Pflugmacher, S., Wiegand, C., Oberemm, A., Beattie, K., Krause, E., Codd, G., and Steinberg, C. (1998). Identification of an enzymatically formed glutathione conjugate of the cyanobacterial hepatotoxin microcystin-LR: The first step of detoxication. Biochim. Biophys. Acta 1425, 527-533.
Råbergh, C. M. I., Bylund, G., and Eriksson, J. E. (1991). Histopathological effects of microcystin-LR, a cyclic peptide toxin from the cyanobacterium (blue-green alga) Microcystis aeruginosa, on common carp (Cyprinus carpio L.). Aquat. Toxicol. 20, 131-146.

Rinehart, K. L., Namikoshi, M., and Choi, B. W. (1994). Structure and biosynthesis of toxins from blue-green algae (cyanobacteria). J. Appl. Phycol. 6, 159-176.

Rodger, H. D., Turnbull, T., Edwards, C., and Codd, G. A. (1994). Cyanobacterial (blue-green-algal) bloom associated pathology in brown trout, Salmo trutta L., in Loch Leven, Scotland. J. Fish Dis. 17, 177-181.

Runnegar, M., Berndt, N., and Kaplowitz, N. (1995). Microcystin uptake and inhibition of protein phosphatases: Effects of chemoprotectants and selfinhibition in relation to known hepatic transporters. Toxicol. Appl. Pharmacol. 134, 264-272.

Sahin, A., Tencalla, F. G., Dietrich, D. R., Mez, K., and Naegeli, H. (1995). Enzymatic analysis of liver samples from rainbow trout for diagnosis of blue-green algae-induced toxicosis. Am. J. Vet. Res. 56, 1110-1116.

Sahin, A., Tencalla, F. G., Dietrich, D. R., and Naegeli, H. (1996). Biliary excretion of biochemically active cyanobacteria (blue-green algae) hepatotoxins in fish. Toxicology 106, 123-130.

Schwimmer, M., and Schwimmer, D. (1968). Medical aspects of phycology. In Algae, Man, and the Environment (D. F. Jackson, Ed.), pp. 279-358. Syracuse University Press, Syracuse, NY.

Stadelmann, P. (1984). Report for the Department of Water Protection and Hydroengineering. Canton Lucern, Switzerland.

Tencalla, F. (1995). Toxicity of cyanobacterial peptide toxins to fish. Ph.D. Thesis, Swiss Federal Institute of Technology, Zurich.

Tencalla, F., and Dietrich, D. (1997). Biochemical characterization of microcystin toxicity in trout (Oncorhynchus mykiss). Toxicon 35, 583-595.

Tencalla, F. G., Dietrich, D. R., and Schlatter, C. (1994). Toxicity of Microcystis aeruginosa peptide toxin to yearling rainbow trout (Oncorhynchus mykiss). Aquat. Toxicol. 30, 215-224.

Watanabe, M. F., Harada, K.-I., Carmichael, W. W., and Fujiki, H. (1996). Toxic Microcystis. CRC Press, Boca Raton, FL.

Williams, D. E., Kent, M. L., Andersen, R. J., Klix, H., and Holmes, C. F. (1995). Tissue distribution and clearance of tritium-labeled dihydromicrocystin-LR epimers administered to Atlantic salmon via intraperitoneal injection. Toxicon 33, 125-131.

Winfield, I. J., and Nelson, J. S. (1991). Cyprinid fishes. Systematics, biology and exploitation. In Fish and Fisheries Series, 1st ed. edited by (I. J. Winfield, Ed.), Chapman \& Hall Publishers, London.

Wyllie, A. H., Kerr, J. F. R., and Currie, A. R. (1980). Cell death: The significance of apoptosis. Int. Rev. Cytol. 68, 251-300.

Yasutake, W. T., and Wales, J. H. (1983). Microscopic Anatomy of Salmonids An Atlas. United States Department of the Interior (Fish and Wildlife Service), Washington D.C. 